\title{
Growth Performance, Nutrient Digestibility, Biochemical Properties, Hematological Traits, and Intestinal Histopathology of Broiler Chicks Fed Mannan Oligosaccharides
} \author{
Khattab $^{3}$, and Yara Ibrahem Youssef ${ }^{2^{*}}$ \\ ${ }^{1}$ Animal Production Department, Faculty of Agriculture, Cairo University, Giza, Egypt \\ ${ }^{2}$ Regional Centre for Food and Feed, Agricultural Research Centre, Giza, Egypt \\ ${ }^{3}$ Pathology Department, Faculty of Veterinary Medicine, Cairo University, Giza, Egypt \\ *Corresponding's Email: yara.ibrahem30@ gmail.com; (D) orciD: 0000-0002-5653-3936
}

Abdallah Ali Ghazalah ${ }^{1}$, Mohamed Ahmed Fouad El-Manylawi ${ }^{1}$, Hady Fathy Abbas Motawe ${ }^{2}$, Marwa Salah

\begin{abstract}
Antibiotics as growth promoters in poultry diets are currently restricted, so other feed additives, such as prebiotics and probiotics, have been suggested as an antibiotics alternative to improve the performance and gut health of poultry. The current experiment was conducted to study the effects of adding Mannan oligosaccharides (MOS) as a potential replacement for an antibiotic on productive performance, nutrient digestibility, some blood parameters, and caecal microbiota of broiler chickens. For conducting the current research experiment, a total of 180 one-day old Ross broiler chicks were randomly divided into one control group fed a basal diet and four dietary treatments with six replicates for each treatment. The treatment groups were fed a basal diet supplemented with different levels of MOS $0.5,1$, and $2 \mathrm{~g} / \mathrm{Kg}$ diet and Lincomycin $4.4 \mathrm{mg} / \mathrm{Kg}$ diet during 35 days of the feeding trial. With exception of the growing period, the group fed a basal diet supplemented with $2 \mathrm{~g} \mathrm{MOS} / \mathrm{Kg}$ feed had considerably higher body weight and weight gain, while having the lowest feed consumption and best feed conversion ratio compared to the other treatment groups, during all experimental periods. Moreover, dietary supplementation of MOS resulted in a significant decrease in the counts of caecal E. coli and Enterococcus, while Lactobacillus and Yeast bacteria counts were significantly higher, compared to non-supplemented groups. Broiler chicks having a $2 \mathrm{~g}$ MOS/kg diet recorded lower values of cholesterol, low-density lipoprotein (LDL), urea, and liver enzymes, including Aspartate transaminase (AST) and Alanine aminotransferase (ALT), while they recorded significantly higher high-density lipoprotein (HDL), compared to the other experimental groups. Group treated with MOS $2 \mathrm{~g} / \mathrm{Kg}$ feed improved digestibility of crude protein, ether extract, crude fiber, nitrogen-free extract, and organic matter, compared to the control group, Additionally, MOS supplementation also increased the intestinal villi length, width, and crypt depth and decreased intestinal inflammation, compared to the control group. In conclusion, supplementation of MOS at 2 $\mathrm{g} / \mathrm{kg}$ diet improved growth performance, digestibility, and blood parameters without having adverse effects on the intestine of broiler chickens, comparable to the Lincomycin.
\end{abstract}

Keywords: Broilers, Digestibility, Growth Performance, Lincomycin, Mannan oligosaccharides

\section{INTRODUCTION}

Optimizing the performance of broilers chicks is the main target of poultry production. To ensure the highest production, broiler chicks must be healthy and offered diets that contain all nutrient requirements needed for optimal production. Using antibiotics as growth promoters in poultry diets is now restricted due to the negative effects on broiler chicks, animal products, and human health (Kovitvadhi et al., 2019). In the past decades, antibiotics have been used to build the immune response of broiler chicks as well as growth promoters (AGP). However, applying antibiotics in poultry feed for long periods may lead to the development of bacteria resistant to drugs, which can be transmitted to the consumer (Sweeney et al., 2018). As a result, the European Union and several advanced countries have completely outlawed the use of antibiotics as growth promoters (Rafeeq and Murad et al., 2017). Consequently, other feed additives such as prebiotics and probiotics have been suggested as an alternative to antibiotics to improve performance and gut health in poultry (Higgins et al., 2008). Nowadays, mannan oligosaccharides (MOS) is a promising prebiotic, obtained from the outer cell wall of the yeast, and can decrease pathogenic bacteria of the gut (Pourabedin et al., 2015; Mahfuz et al., 2019) and enhance intestinal mucosal health leading to a balance between useful and harmful microorganisms (Kim et al., 2016). In addition, MOS can serve as an energy source for useful microorganisms like Lactobacillus and Bifidobacterium species (Leblebicier and Aydogan, 2018). The mode of action of MOS provides nutrients to the intestinal microflora and prevents the attachment of pathogens, such as Escherichia Coli (E. coli) to the intestinal mucosa (Attia et al., 2014). Moreover, the decrease in harmful bacteria and increase in beneficial bacteria may be due to receptor site competition and the production of volatile fatty acids by bacteriocins in combination with IgA antibodies, resulting in a strong immunological response (Kim et al., 2009). Therefore, the current study aimed to evaluate the effect 
of prebiotics (MOS) and antibiotics (Lincomycin) as growth promoters on growth performance, nutrient digestibility, blood biochemical, hematological parameters, and gut histology in broiler chicks.

\section{MATERIALS AND METHODS}

\section{Ethical approval}

The experimental protocol used in the present study was approved by the Institutional Animal Care and Use Committee of Cairo University, Egypt (CU-IACUC) with approval number CU/I/F/33/20.

\section{Experimental design and management}

The current experiment was carried out at the Faculty of Agriculture, Cairo University, Egypt using a total of 180, one-day-old, unsexed Ross broiler chicks with average initial body weight (BW) of $40 \pm 1 \mathrm{~g}$. The broiler chicks were randomly distributed into five treatment groups (6 replicates with 6 broiler chicks per replicate) using a completely randomized design. The treatment groups were fed basal diets supplemented with MOS at $0,0.5,1$, and $2 \mathrm{~g} / \mathrm{kg}$ diet, and the last one was supplemented with Lincomycin antibiotic as an antibiotic growth promoter (AGP) at $4.4 \mathrm{mg} / \mathrm{kg}$ diet, respectively. Commercial Mannan oligosaccharides (Bio-MOS $($ ) $)$ were purchased from the Multi Vita for Animal Nutrition Company, Egypt. Lincomycin was obtained as Lincomycin Hydrochloride (Lincomix 44 premix ${ }^{\circledR}$ ) from the International Free Trade Corporation (IFT) company, The basal diets were mycotoxins-free and contained 23, 21. and $19 \%$ Crude Protein (CP) along with 3000, 3150, and $3200 \mathrm{kcal} \mathrm{ME} / \mathrm{kg}$, and offered to broiler chickens during 1-14, 1528, and 29-35 days as starter, grower, and finisher diets, respectively. Aflatoxin and other mycotoxins levels in diets were below the detection limit (1 ppb) (Ross et al., 1997). There were no medications or antibiotics in the basal diets. At the poultry research unit, faculty of agriculture, Cairo University, Egypt, according to the National Research Council (NRC, 1994), the diets were formulated to meet the nutrient requirements of broiler chicks during the starting, growing, and finishing periods.

Table 1. Ingredients and calculated analysis of the experimental basal diets for Ross broiler chicks introduced during experimental periods (35 days) at the poultry research unit, Cairo University, Egypt

\begin{tabular}{|c|c|c|c|}
\hline Ingredients & Starter (kg) & Grower (kg) & Finisher (kg) \\
\hline Corn, grains $(7.5 \% \mathrm{CP})$ & 54.32 & 58.74 & 65.04 \\
\hline Soybean meal $(46.0 \% \mathrm{CP})$ & 34.46 & 28.98 & 23.72 \\
\hline Corn gluten meal $(60.0 \% \mathrm{CP})$ & 4.98 & 5.01 & 4 \\
\hline Vegetable oil & 2.01 & 3.25 & 3.17 \\
\hline Dicalcium phosphate & 1.7 & 1.75 & 1.75 \\
\hline Limestone & 1.54 & 1.15 & 1.3 \\
\hline Vit.Mixture $^{1}$ & 0.05 & 0.03 & 0.07 \\
\hline Min. Mixture ${ }^{2}$ & 0.1 & 0.1 & 0.1 \\
\hline Salt & 0.42 & 0.4 & 0.4 \\
\hline L-lysine-HCl & 0.15 & 0.22 & 0.15 \\
\hline DL-Methionine & 0.15 & 0.25 & 0.18 \\
\hline Choline chloride & 0.12 & 0.12 & 0.12 \\
\hline Total & 100 & 100 & 100 \\
\hline \multicolumn{4}{|l|}{ Calculated values } \\
\hline $\mathrm{ME}(\mathrm{KCal} / \mathrm{Kg})$ & 3000 & 3150 & 3200 \\
\hline $\mathrm{CP}$ & 23 & 21 & 19 \\
\hline Ether Extract & 4.6 & 5.97 & 6.09 \\
\hline Crude Fiber & 2.45 & 3.09 & 2.34 \\
\hline Lysine & 1.36 & 1.3 & 1.13 \\
\hline Methionine & 0.61 & 0.58 & 0.51 \\
\hline Methionine + Cystine & 0.98 & 0.94 & 0.85 \\
\hline Calcium & 0.96 & 0.9 & 0.85 \\
\hline Available P & 0.45 & 0.48 & 0.44 \\
\hline
\end{tabular}

Ross broiler chicks were fed the starter diet from the first day to fourteen days of age, followed by the grower diet from 15 to 28 days of age, and then switched to the finisher diet during 29 to 35 days of age Table 1. Feed and water were available ad-libitum during the experimental period ( 35 days). The temperature was adjusted at $30 \pm 0.5^{\circ} \mathrm{C}$ in the first week then lowered by $2^{\circ} \mathrm{C}$ each successive week, and then maintained at $24 \pm 0.5^{\circ} \mathrm{C}$. Relative humidity was about $60 \%$ to $70 \%$ during the first week of age then, dropped to $50-60 \%$ from the second week of age until the end of the experiment. During the first week of the experiment, the broiler chicks were exposed to 23 hours of light and 1 hour of darkness during the day. The daily lighting program was adjusted to 20 hours light and 4 hours dark from the second 
week up to the end of the experiment. Chicks were vaccinated against Infection Bronchitis (IB) at 6 days of age, Avian Influenza a (H5N1) Virus at day 9, infection bursal disease (IBD) at 13 and 24 days of age. During all periods of growth, body weight (BW) and feed intake (FI) were recorded weekly for each replicate; accordingly, body weight gain and feed conversion ratio were easily calculated.

\section{Caecal contents}

At 35 days of age, five chickens from each treatment group were slaughtered and caecal contents were taken for bacterial count including Lactobacillus, Enterococcus, E. coli, Yeast, and Salmonella as well as determining $\mathrm{pH}$ (Collin et al., 1995).

\section{Blood parameters}

Blood samples were collected at the end of the experiment from the wing vein of three individuals per treatment into $2 \mathrm{~mL}$ sterile vials and allowed to clot for 4 hours. The serum was collected and kept at $-20^{\circ} \mathrm{C}$ until further analysis after centrifugation (10 minutes, $2000 \mathrm{rpm}$ ). Liver function indicators including aspartate aminotransferase (AST) and alanine aminotransferase (ALT); kidney function indices including urea and creatinine were determined in the collected serum using Bahman et al. (2011) methods. Lipid profiles including triglycerides, low-density lipoprotein (LDL), highdensity lipoprotein (HDL), and cholesterol were measured in serum using commercially available kits (Biosystem S.A., Costa Brava, 30, Barcelona, Spain) according to manufacturer's instructions. Moreover, at 35 days of age, another blood samples were collected into $2 \mathrm{~mL}$ sterile vials containing anticoagulant (EDTA K3) for measuring red blood cell count (RBC), hemoglobin ( $\mathrm{Hb}$ ) content, total leukocyte counts (WBCs), lymphocytes (L) and heterophils (H) according to Ewuola and Egbunike (2008). At the same time, 'H/L ratio was calculated. The hematology parameters were determined by an automated hematology analyzer for animals (Sysmex XT-2000iV, KOBE, JAPAN) using Sysmex software (version, 00-11) of an automated hematology analyzer for the animal, (XT-2000iV, KOBE, JAPAN) and (Sysmex) software (version, 00-11) according to manufacturer's instructions.

\section{Digestibility trial}

A digestibility trial was conducted after the end of the experiment using four broiler chicks from each treated group over a four-day collecting period. To determine the apparent digestibility (AD) of nutrients, the total collection method cited by Abou-Raya and Galal (1971) was executed. The number (N), ether extract (EE), crude fiber (CF), and ash content of dried excreta, as well as those of feed, were determined using N. 928.08, 2003.06, 2011.25, and 920.153 procedures, respectively, according to AOAC (2016). The amount of nitrogen-free extract (NFE) on a dry matter basis was obtained by the difference that is by deducting the sum of the percentage of ash, crude protein, EE, and CF from hundred for food materials. For dung material, urinary organic matter was calculated as urinary-N X 2.62 (Sturkie, 1954). Fecal NFE on a dry matter basis was then calculated as follows:

Fecal NFE $\%=100-(\operatorname{ash} \%+\mathrm{FCP} \%+\mathrm{EE} \%+$ urinary $\mathrm{OM} \%+\mathrm{CF} \%)$.

Fecal nitrogen of dried excreta collected from the experimental digestibility trial was determined according to the method by (Jakobsen et al., 1960).

\section{Histopathology}

A tissue specimen was collected from the intestine of broiler chickens of all groups (two chickens of each replicate) and fixed in $10 \%$ neutral buffered formalin for 72 hours. Fixed tissue was processed by xylene and ethyl alcohol, embedded in paraffin, sectioned into $4 \mu \mathrm{m}$ thick sections using a microtome (Leica 2135 , Germany) into $4 \mu \mathrm{m}$ thick sections and stained by hematoxylin and eosin stain (Suvarna et al., 2012). Stained tissue was examined using a light microscope and photographed using a digital camera (Olympus XC30, Tokyo, Japan). Morphometric analysis of the length, width, and crypt depth of intestinal villi was performed using TS view Software. Three intestinal villi were measured in three captured images at magnification $40 \times$ to calculate the mean for each chicken (Mohamed et al., 2020).

\section{Economic efficiency of feeding}

To determine the economic efficiency (EE) of dietary treatments, broiler meat production administration factors in all treatments were considered to be constants but weight gains and feed consumption per treatment were calculated. The price of feed additives (MOS and Lincomycin) and basal diets were calculated according to the cost of the native market at the timing of the experiment. The EE of feeding was represented as (Net revenue / total cost) (Saad et al., 2014).

\section{Statistical analysis}

The data were statistically analyzed by the least-squares procedure of the general linear model (GLM) of SAS program (SAS, 2010). The separation of means was done using Duncan's New Multiple Range Test (Duncan, 1955) for 
comparisons among the significant means at 0.05 significant levels. The fixed model used in the analysis was $Y_{i j}=\mu+$ $\mathrm{T}_{\mathrm{i}}+\varepsilon_{\mathrm{ij}}$, where, $\mathrm{Y}_{\mathrm{ij}}$ is the value of the respective variable, $\mu$ signifies the overall mean of the respective variable, Ti denotes $\mathrm{i}^{\text {th }}$ treatments effect, $\mathrm{i}$ refers to $1,2, \ldots$, and $5(1=$ Control, $2=0.5 \mathrm{~g}$ Mannan, $3=1 \mathrm{~g}$ Mannan, $4=2 \mathrm{~g}$ Mannan, and $5=4.4 \mathrm{mg}$ Lincomycin), and $\varepsilon_{\mathrm{ij}}$ is the experimental random error.

\section{RESULTS}

\section{Productive performance}

The performance traits were affected by the supplementation of MOS and lincomycin as an AGP into the diets of broiler chickens (Table 2). There were highly significant differences between treatment groups in terms of BW, BWG, FI, and FCR during all periods from 1 to 35 days $(\mathrm{p}<0.05)$. The results revealed that the group fed a basal diet supplemented with $2 \mathrm{~g} \mathrm{MOS} / \mathrm{Kg}$ had the highest significant growth performance in BW and BWG, lower in FI, and expressed the best FCR when compared to the other treatment groups at the starter, grower, and finisher experimental periods.

Table 2. Broiler production performance at 35 days of age as affected by diets supplemented with different levels of Mannan oligosaccharides or Lincomycin at the poultry research unit, Cairo University, Egypt

\begin{tabular}{|c|c|c|c|c|c|c|}
\hline Traits & Control & $\begin{array}{c}\text { MOS } \\
(0.5 \mathrm{~g} / \mathrm{kg})\end{array}$ & $\begin{array}{c}\text { MOS } \\
(1 \mathrm{~g} / \mathrm{kg})\end{array}$ & $\begin{array}{c}\text { MOS } \\
(2 \mathrm{~g} / \mathrm{kg})\end{array}$ & $\begin{array}{l}\text { Lincomycin } \\
(4.4 \mathrm{mg} / \mathrm{kg})\end{array}$ & SEM \\
\hline \multicolumn{7}{|l|}{ 1-14 days } \\
\hline $\mathrm{BW},(\mathrm{g})$ & $492.71^{\mathrm{d}}$ & $511.5^{\mathrm{ab}}$ & $500.33^{c}$ & $516^{\mathrm{a}}$ & $506.5^{b}$ & 2.02 \\
\hline BWG, $(\mathrm{g})$ & $452.71^{\mathrm{d}}$ & $471.5^{\mathrm{ab}}$ & $460.33^{c}$ & $476^{\mathrm{a}}$ & $466.5^{\mathrm{b}}$ & 2.02 \\
\hline FI, (g) & $531.17^{\mathrm{a}}$ & $499.67^{\mathrm{b}}$ & $501.67^{\mathrm{b}}$ & $495.67^{\mathrm{b}}$ & $501.67^{\mathrm{b}}$ & 2.2 \\
\hline FCR & $1.17^{\mathrm{a}}$ & $1.06^{\mathrm{d}}$ & $1.09^{\mathrm{b}}$ & $1.04^{\mathrm{e}}$ & $1.08^{\mathrm{c}}$ & 0.005 \\
\hline $\mathrm{BW},(\mathrm{g})$ & $1502.67^{b}$ & $1565^{\mathrm{a}}$ & $1525.33^{b}$ & $1571.5^{\mathrm{a}}$ & $1525^{\mathrm{b}}$ & 7.78 \\
\hline BWG, (g) & $1009.96^{\mathrm{b}}$ & $1053.5^{\mathrm{a}}$ & $1025^{b}$ & $1055.5^{\mathrm{a}}$ & $1018.5^{\mathrm{b}}$ & 7.28 \\
\hline FI, (g) & $1613.17^{\mathrm{a}}$ & $1587.83^{\mathrm{ab}}$ & $1591.33^{\mathrm{ab}}$ & $1577.33^{\mathrm{b}}$ & $1597.33^{\mathrm{ab}}$ & 10.5 \\
\hline FCR & $1.6^{\mathrm{a}}$ & $1.51^{\mathrm{c}}$ & $1.55^{\mathrm{b}}$ & $1.50^{\mathrm{c}}$ & $1.57^{\mathrm{ab}}$ & 0.01 \\
\hline $\mathrm{BW},(\mathrm{g})$ & $2225.67^{\mathrm{c}}$ & $2322.5^{\mathrm{ab}}$ & $2282^{b}$ & $2354.17^{\mathrm{a}}$ & $2288.33^{b}$ & 13.88 \\
\hline $\mathrm{BWG},(\mathrm{g})$ & $723^{\mathrm{b}}$ & $757.5^{\mathrm{ab}}$ & $756.67^{\mathrm{ab}}$ & $782.67^{\mathrm{a}}$ & $763.33^{\mathrm{ab}}$ & 14.75 \\
\hline FI, (g) & $1403.83^{\mathrm{a}}$ & $1327.83^{\mathrm{cd}}$ & $1345.33^{\mathrm{b}}$ & $1318.83^{\mathrm{d}}$ & $1335.33^{b c}$ & 5.6 \\
\hline FCR & $2.02^{\mathrm{a}}$ & $1.76^{\mathrm{bc}}$ & $1.80^{\mathrm{b}}$ & $1.69^{c}$ & $1.76^{\mathrm{bc}}$ & 0.03 \\
\hline $\mathrm{BW},(\mathrm{g})$ & $2225.67^{\mathrm{c}}$ & $2322.5^{\mathrm{ab}}$ & $2282^{b}$ & $2354.17^{\mathrm{a}}$ & $2288.33^{b}$ & 13.88 \\
\hline BWG, (g) & $2185.67^{\mathrm{c}}$ & $2282.5^{\mathrm{ab}}$ & $2242^{b}$ & $2314.17^{\mathrm{a}}$ & $2248.33^{\mathrm{b}}$ & 13.88 \\
\hline FI, (g) & $3548.17^{\mathrm{a}}$ & $3415.33^{b c}$ & $3438.33^{b}$ & $3391.83^{c}$ & $3434.33^{\mathrm{b}}$ & 12.02 \\
\hline FCR & $1.63^{\mathrm{a}}$ & $1.5^{\mathrm{c}}$ & $1.54^{\mathrm{b}}$ & $1.47^{\mathrm{d}}$ & $1.53^{\mathrm{b}}$ & 0.008 \\
\hline
\end{tabular}

$\overline{a, b, c, \text { and d }}$ Means different letters within each row are significantly different ( $\mathrm{p}<0.05)$, SEM: Standard error mean from the least square mean.

BW: Body weight, BWG: Body weight gain, FI: Feed intake, FCR: Feed conversion ratio, and MOS: Mannan oligosaccharides.

\section{Microbial content of caecum}

There were highly significant differences in E. coil, Lactobacillus, Enterococcus bacteria, and yeast counts in the caecum of experimental broiler chicks at 35 days of age (Table 3). A significant decrease in the caecal E. coli and Enterococcus counts, and a significant increase in the Lactobacillus and Yeast counts were found due to the inclusion of Bio-MOS in supplementing the diets of broilers. Compared to the Lincomycin and control groups, the group that fed a basal diet supplemented with $2 \mathrm{~g} \mathrm{MOS} / \mathrm{Kg}$ diet had the significantly highest Lactobacillus count and yeast, while it had the lowest E. coli and Enterococcus counts, compared to other treatments. On the other hand, there was a significant difference $(\mathrm{p}<0.05)$ in the $\mathrm{pH}$ level among groups, obtaining the highest level in the control group (7.48) and the lowest level in the group fed supplemented with a $2 \mathrm{~g} \mathrm{MOS} / \mathrm{Kg} / \mathrm{diet}$ (6.94). However, the $\mathrm{pH}$ was generally neutralized in all experimental groups.

Table 3. Broiler microbiota as affected by diets supplemented with different levels of Mannan oligosaccharides diet or Lincomycin at 35 days of age

\begin{tabular}{lcccccc}
\hline Treatment & $\begin{array}{c}\text { Lact. count } \\
(\mathbf{c f u} / \mathbf{g})\end{array}$ & $\begin{array}{c}\text { E. coli } \\
(\mathbf{c f u} / \mathbf{g})\end{array}$ & $\mathbf{p H}$ & $\begin{array}{c}\text { En. count } \\
(\mathbf{c f u} / \mathbf{g})\end{array}$ & $\begin{array}{c}\text { Yeast } \\
(\mathbf{c f u} / \mathbf{g})\end{array}$ & Salmonella \\
\hline Control & $4.66^{\mathrm{c}}$ & $4.4^{\mathrm{a}}$ & $7.48^{\mathrm{a}}$ & $6.16^{\mathrm{a}}$ & $2.8^{\mathrm{b}}$ & $\mathrm{ND}$ \\
MOS $(0.5 \mathrm{~g} / \mathrm{kg})$ & $5.13^{\mathrm{ab}}$ & $2.96^{\mathrm{b}}$ & $7.1^{\mathrm{c}}$ & $5.13^{\mathrm{b}}$ & $3.36^{\mathrm{ab}}$ & $\mathrm{ND}$ \\
MOS $(1 \mathrm{~g} / \mathrm{kg})$ & $4.8^{\mathrm{b}}$ & $3.2^{\mathrm{b}}$ & $7.26^{\mathrm{b}}$ & $5.03^{\mathrm{bc}}$ & $3.53^{\mathrm{a}}$ & $\mathrm{ND}$ \\
MOS $(2 \mathrm{~g} / \mathrm{kg})$ & $5.46^{\mathrm{a}}$ & $1.96^{\mathrm{c}}$ & $6.94^{\mathrm{d}}$ & $4.8^{\mathrm{d}}$ & $3.56^{\mathrm{a}}$ & $\mathrm{ND}$ \\
Lincomycin$(4.4 \mathrm{mg} / \mathrm{kg})$ & $4.7^{\mathrm{bc}}$ & $3.86^{\mathrm{ab}}$ & $7.31^{\mathrm{b}}$ & $4.9^{\mathrm{c}}$ & $2.3^{\mathrm{c}}$ & $\mathrm{ND}$ \\
SEM & 0.16 & 0.29 & 0.10 & 0.24 & 0.20 & - \\
\hline
\end{tabular}

$\overline{\mathrm{a}, \mathrm{b}, \mathrm{c}, \text { and d }}$ Means, different letters within each column, are significantly different ( $\mathrm{p}<0.05$ ), SEM: Standard error mean from least square mean, Cfu/g: Colony forming unite/gram, Lact: Lactobacillus, E. coli: Escherichia coli, En: Enterococcus, ND: Not detected, MOS: Mannan oligosaccharides. 


\section{Blood parameters}

As presented in Table 4, there was a significant decrease in the cholesterol, LDL, urea, AST, and ALT, of the group that fed $2 \mathrm{~g} \mathrm{MOS} / \mathrm{Kg}$ diet while the HDL was significantly $(\mathrm{p}<0.05)$ increased compared to the control and the other treatment groups. In contrast, the creatinines of all treated groups with MOS or Lincomycin were significantly $(\mathrm{p}<0.05)$ lowers than those in the control group. The results of blood count (CBC) as affected by MOS or Lincomycin treatment in broilers chickens were presented in Table 5. The highest present level of $\mathrm{Hb}$ was obtained in the group that fed a $2 \mathrm{~g}$ MOS/kg diet, compared to the other groups $(\mathrm{p}<0.05)$. In contrast, the lowest Heterophile level was found in the group treated with $2 \mathrm{~g}$ MOS in comparison with the control and other treatment groups. In addition, the H/L ratio was significantly decreased $(\mathrm{p}<0.05)$ in MOS $(2 \mathrm{~g} / \mathrm{kg}$ diet $)$ and Lincomycin treated groups in comparison to the control group. The percentage of lymphocytes, as well as the percentage of RBCs and WBCs, did not show any significant between the experimental groups.

Table 4. Broiler's blood serum analysis as affected by dietary supplementation with Mannan oligosaccharides or Lincomycin at 35 days of age

\begin{tabular}{|c|c|c|c|c|c|c|c|}
\hline Treatment & $\begin{array}{c}\text { Cholesterol } \\
\text { (mg/dl) }\end{array}$ & $\begin{array}{c}\text { LDL } \\
(\mathrm{mg} / \mathrm{dl})\end{array}$ & $\begin{array}{c}\text { HDL } \\
\text { (mg/dl) }\end{array}$ & $\begin{array}{c}\text { Urea } \\
\text { (mg/dl) }\end{array}$ & $\begin{array}{c}\text { Creatinine } \\
\text { (mg/dl) }\end{array}$ & $\begin{array}{c}\text { AST } \\
(\mathbf{U} / \mathbf{L})\end{array}$ & $\begin{array}{c}\text { ALT } \\
\text { (U/L) }\end{array}$ \\
\hline Control & $129.23^{\mathrm{a}}$ & $59^{\mathrm{a}}$ & $38.7^{\mathrm{c}}$ & $4.23^{\mathrm{c}}$ & $0.23^{\mathrm{a}}$ & $114^{\mathrm{a}}$ & $17^{\mathrm{a}}$ \\
\hline $\operatorname{MOS}(0.5 \mathrm{~g} / \mathrm{kg})$ & $126.1^{\mathrm{b}}$ & $47.6^{\mathrm{b}}$ & $65.96^{\mathrm{a}}$ & $4.5^{\mathrm{a}}$ & $0.2^{\mathrm{b}}$ & $90.66^{\mathrm{b}}$ & $13.66^{\mathrm{b}}$ \\
\hline $\operatorname{MOS}(1 \mathrm{~g} / \mathrm{kg})$ & $113.43^{\mathrm{c}}$ & $42^{\mathrm{c}}$ & $61^{\mathrm{b}}$ & $4.06^{\mathrm{d}}$ & $0.2^{\mathrm{b}}$ & $78.66^{\mathrm{c}}$ & $14^{\mathrm{b}}$ \\
\hline $\operatorname{MOS}(2 \mathrm{~g} / \mathrm{kg})$ & $106.3^{\mathrm{d}}$ & $39.13^{\mathrm{d}}$ & $66.56^{\mathrm{a}}$ & $4^{\mathrm{e}}$ & $0.2^{\mathrm{b}}$ & $66.33^{\mathrm{d}}$ & $11^{\mathrm{d}}$ \\
\hline Lincomycin $(4.4 \mathrm{mg} / \mathrm{kg})$ & $128.83^{\mathrm{a}}$ & $47.66^{\mathrm{b}}$ & $60.33^{\mathrm{b}}$ & $4.43^{\mathrm{b}}$ & $0.2^{\mathrm{b}}$ & $76.66^{\mathrm{c}}$ & $12^{\mathrm{c}}$ \\
\hline SEM & 0.43 & 2.66 & 2.38 & 0.1 & 0.009 & 2.54 & 1.06 \\
\hline
\end{tabular}

Table 5. Broiler's blood hematology as affected by diets supplemented with different levels of Mannan oligosaccharides (g/ kg diet) or Lincomycin (mg/ kg diet) at 35 days of age

\begin{tabular}{|c|c|c|c|c|c|c|}
\hline Variable & Control & $\begin{array}{c}\text { MOS } \\
(0.5 \mathrm{~g} / \mathrm{kg})\end{array}$ & $\begin{array}{c}\text { MOS } \\
(1 \mathrm{~g} / \mathrm{kg})\end{array}$ & $\begin{array}{c}\text { MOS } \\
(2 \mathrm{~g} / \mathrm{kg})\end{array}$ & $\begin{array}{l}\text { Lincomycin } \\
(4.4 \mathrm{mg} / \mathrm{kg})\end{array}$ & SEM \\
\hline $\mathrm{Hb}(\%)$ & $9.94^{\mathrm{e}}$ & $10.23^{\mathrm{d}}$ & $10.35^{b}$ & $10.62^{\mathrm{a}}$ & $10.32^{\mathrm{c}}$ & 0.11 \\
\hline RBCs $($ Cells $/ \mu \mathrm{L})$ & 2.16 & 2.81 & 2.8 & 2.95 & 2.80 & 0.11 \\
\hline WBCs $\left(19-30 \times 10^{3} / \mathrm{mm}^{3}\right)$ & 25.66 & 21 & 23.33 & 20.66 & 23.66 & 1.58 \\
\hline Lymphocytes (\%) & 69 & 67.33 & 64.66 & 69 & 70 & 1.75 \\
\hline Heterophile (\%) & $36.5^{\mathrm{a}}$ & $35.67^{\mathrm{b}}$ & $33.75^{\mathrm{c}}$ & $30.33^{\mathrm{e}}$ & $32.5^{\mathrm{d}}$ & 0.06 \\
\hline $\mathrm{H} / \mathrm{L}$ ratio & $0.52^{\mathrm{a}}$ & $0.52^{\mathrm{b}}$ & $0.52^{\mathrm{b}}$ & $0.43^{\mathrm{c}}$ & $0.46^{\mathrm{c}}$ & 0.03 \\
\hline
\end{tabular}

a,b,c,d, and ${ }^{\mathrm{e}}$ Means different letters within each row are significantly different ( $<$ 0.05), SEM: Standard error mean from least square mean, Hb: Hemoglobin, RBCs: Reed blood cells, WBCs: White blood cells, MOS: Mannan oligosaccharides, H: Heterophile, L: Lymphocytes.

\section{Nutrient digestibility}

The results of nutrient digestibility in broiler chickens treated with MOS or Lincomycin are shown in Table 6. It was observed that supplementing broiler chickens' diet with $1 \mathrm{~g}$ and $2 \mathrm{~g}$ MOS improved the digestibility of CP, NFE, and OM, compared to the control and Lincomycin groups. In contrast, the treatment with $2 \mathrm{~g}$ MOS or Lincomycin significantly increased the digestibility of EE and CF compared to the control.

Table 6. Digestibility of nutrients in broilers chickens' fed diet supplemented with different levels of Mannan oligosaccharides or Lincomycin at the poultry research unit, faculty of agriculture, Cairo University, Egypt

\begin{tabular}{lccccc}
\hline Treatment & $\begin{array}{c}\text { Crude protein } \\
\mathbf{( \% )}\end{array}$ & $\begin{array}{c}\text { Ether extract } \\
\mathbf{( \% )}\end{array}$ & $\begin{array}{c}\text { Crude fiber } \\
(\mathbf{\%})\end{array}$ & $\begin{array}{c}\text { Nitrogen free } \\
\text { extract } \mathbf{( \% )}\end{array}$ & $\begin{array}{c}\text { Organic matter } \\
(\mathbf{\%})\end{array}$ \\
\hline Control & $89.01^{\mathrm{b}}$ & $75.08^{\mathrm{b}}$ & $20^{\mathrm{bc}}$ & $73.24^{\mathrm{c}}$ & $72.21^{\mathrm{c}}$ \\
MOS (0.5 g/Kg diet) & $89.98^{\mathrm{ab}}$ & $69.63^{\mathrm{c}}$ & $18.58^{\mathrm{c}}$ & $75.23^{\mathrm{bc}}$ & $73.94^{\mathrm{b}}$ \\
MOS (1 g/Kg diet) & $91.21^{\mathrm{a}}$ & $76.06^{\mathrm{b}}$ & $19.75^{\mathrm{bc}}$ & $76.79^{\mathrm{b}}$ & $75.51^{\mathrm{ab}}$ \\
MOS (2 g/Kg diet) & $89.85^{\mathrm{ab}}$ & $80.54^{\mathrm{a}}$ & $20.85^{\mathrm{b}}$ & $77.66^{\mathrm{a}}$ & $76.8^{\mathrm{a}}$ \\
Lincomycin (4.4 mg/Kg diet) & $85.44^{\mathrm{c}}$ & $79.08^{\mathrm{a}}$ & $24.33^{\mathrm{a}}$ & $74.67^{\mathrm{c}}$ & $71.52^{\mathrm{d}}$ \\
SEM & 0.63 & 0.61 & 0.58 & 0.63 & 0.63 \\
a,b,c, and Means different letters within each row are significantly different $(\mathrm{p}<0.05)$, SEM: Standard error mean from least square mean, MOS: Mannan \\
oligosaccharides.
\end{tabular}

\section{Intestinal histomorphometry and histopathology}

The intestinal villi length in chickens supplemented with MOS recorded a significant increase, compared to the control group. The highest increase was observed in the group supplemented with a $2 \mathrm{~g} \mathrm{MOS} / \mathrm{kg}$ diet, compared to all other groups. The intestinal width was also increased significantly in a dose-dependent manner in the groups supplemented with MOS, compared to control. The crypt depth also was increased in all groups supplemented with MOS with the highest increase in MOS $(0.5 \mathrm{~g} / \mathrm{kg})$ and the least increase in MOS $(2 \mathrm{~g} / \mathrm{kg})$ as compared with the control group (Table 7). 
Microscopy of the intestine in the control group revealed mucous exudates in the lumen, slight shortening of intestinal villi, few goblet cell hyperplasias', and few inflammatory cells infiltration in the lamina propria and submucosa (Figure 1a). Similar lesions were detected in the group provided with a $0.5 \mathrm{~g} \mathrm{MOS} / \mathrm{kg}$ diet. However, the intestinal villi were longer and wider, with moderate mononuclear cells infiltrating the lamina propria and submucosa. In addition severe epithelial and goblet cell hyperplasia were observed (Figure 1b). Microscopy of the chicken intestine in the group fed MOS at $1 \mathrm{~g} / \mathrm{kg}$ diet revealed severe goblet cell hyperplasia and widening of intestinal villi with mononuclear cell infiltration (Figure 1c). For group fed MOS at $2 \mathrm{~g} / \mathrm{kg}$ basal diet, the intestinal villi were tall in some sections with few mononuclear leukocyte infiltrations and moderate goblet cell hyperplasia (Figure 1d). In the lincomycin group, the tips of intestinal villi were necrosed in some intestinal sections. Goblet cell hyperplasia was moderate and the lamina propria and submucosa were infiltrated by numerous mononuclear cells (Figure 1e).

\section{The economic efficiency}

As shown in Table 8, the dietary treatment with MOS $(2 \mathrm{~g} / \mathrm{kg}$ diet $)$ exhibited the best values of net return and EE. According to Table 8 , the lowest cost $/ \mathrm{kg}$ body weight (28.19 EGP) was observed when chicks were fed diets supplemented with lincomycin, followed by those supplemented with MOS (at $0.5,1$, and $2 \mathrm{~g} / \mathrm{kg}$ ), respectively, while the highest cost per $\mathrm{kg} \mathrm{BW}$ (28.85 EGP) was recorded in the control group.

Table 7. The morphology of broiler chickens' intestine at 35 days of age affected by diets supplemented with different levels of Mannan oligosaccharides or Lincomycin

\begin{tabular}{lccc}
\hline Treatment & Length $(\boldsymbol{\mu m})$ & Width $(\boldsymbol{\mu m})$ & Depth $(\boldsymbol{\mu m})$ \\
\hline Control & $818.43^{\mathrm{d}}$ & $153.45^{\mathrm{c}}$ & $120.71^{\mathrm{e}}$ \\
MOS $(0.5 \mathrm{~g} / \mathrm{kg})$ & $1089.53^{\mathrm{b}}$ & $159.06^{\mathrm{b}}$ & $279.44^{\mathrm{a}}$ \\
MOS $(1 \mathrm{~g} / \mathrm{kg})$ & $1029.08^{\mathrm{c}}$ & $174.26^{\mathrm{a}}$ & $240.18^{\mathrm{b}}$ \\
MOS $(2 \mathrm{~g} / \mathrm{kg})$ & $1389.57^{\mathrm{a}}$ & $187.37^{\mathrm{a}}$ & $221.36^{\mathrm{c}}$ \\
Lincomycin $(\mathrm{mg} / \mathrm{kg})$ & $1038.44^{\mathrm{c}}$ & $158.49^{\mathrm{b}}$ & $190.86^{\mathrm{d}}$ \\
SEM & 58.27 & 12.47 & 14.84 \\
\hline a,b,c,c, and $\mathrm{e}$ &
\end{tabular}

$\overline{\mathrm{a}, \mathrm{b}, \mathrm{c}, \mathrm{d}, \text { and } \mathrm{e}}$ Means different letters within each column are significantly different ( $\mathrm{p}<0.05)$, SEM: Standard error mean from the least square mean, MOS: Manna oligosaccharides.

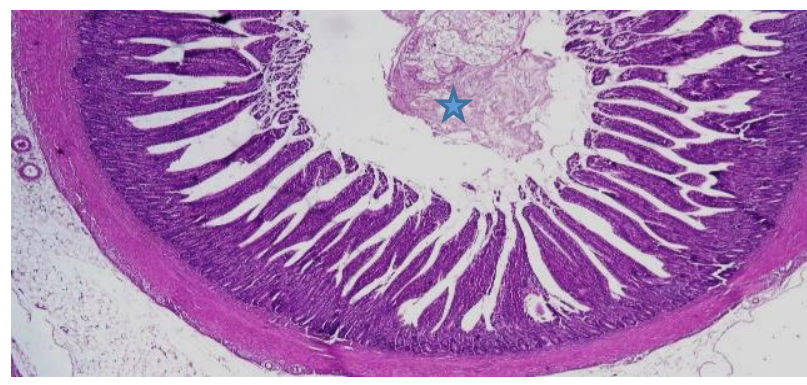

a

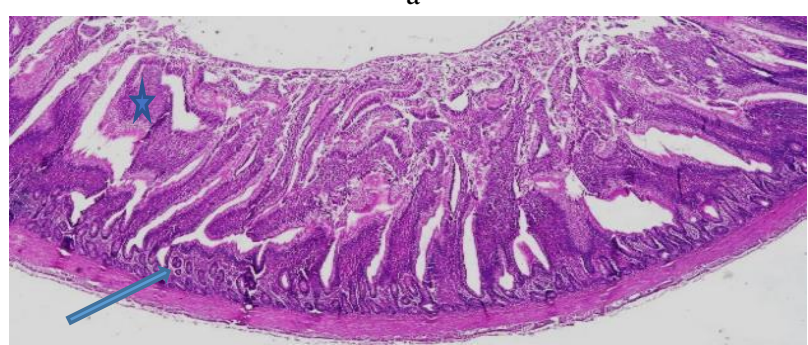

$\mathrm{c}$

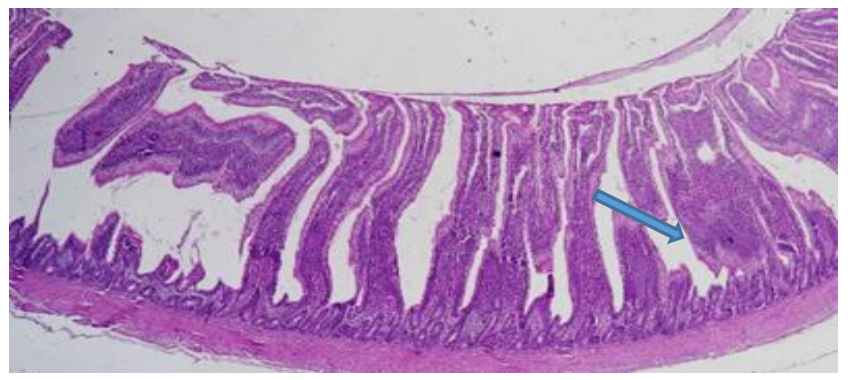

b

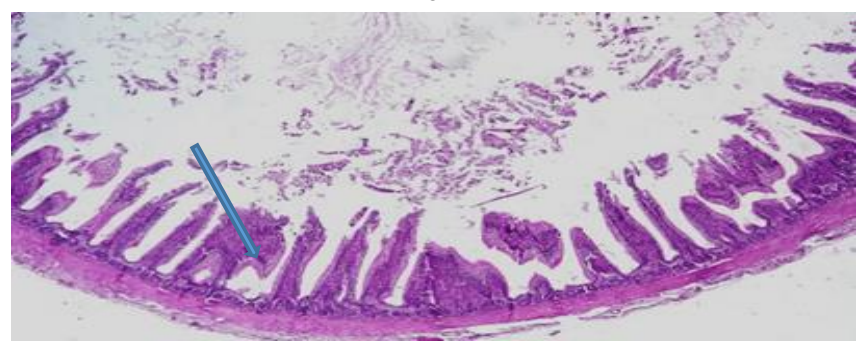

d

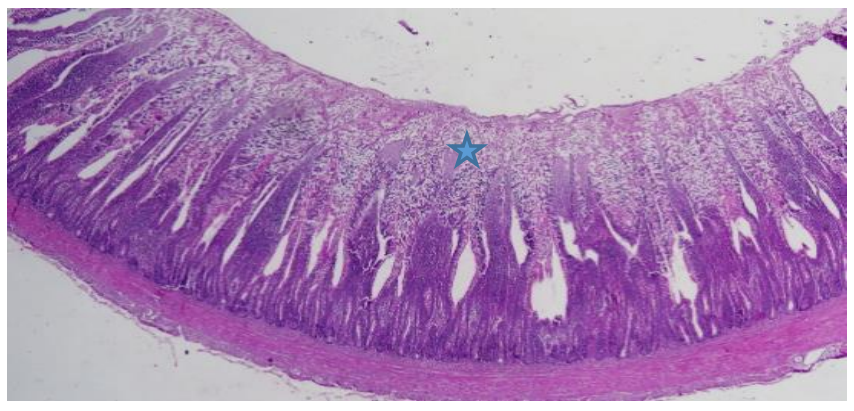

e

Figure 1. Intestine of Ross broiler chickens fed Manna oligosaccharides at 35 days of age. a: showing mucous exudates (star) in the lumen and slight shortening of intestinal villi (control group), b: Manna oligosaccharides (MOS, $0.5 \mathrm{~g} / \mathrm{kg}$ ) showing long and wide intestinal villi with epithelial hyperplasia (arrow), c: MOS $(1 \mathrm{~g} / \mathrm{kg}$ ) showing severe goblet cell hyperplasia (star) and widening of intestinal villi with mononuclear leukocytes (arrow), d: MOS $(2 \mathrm{~g} / \mathrm{kg}$ ) showing few mononuclear leukocytes infiltration and moderate goblet cell hyperplasia (arrow) and e: Lincomycin $(4.4 \mathrm{mg} / \mathrm{kg}$ ) showing necrosis of intestinal villi tips (star) with severe diffuse mononuclear leukocytes infiltration. 
Table 8. Effect of dietary Mannan oligosaccharides and lincomycin on the economic efficiency of broiler chickens' production from 1 to 35 days of age

\begin{tabular}{|c|c|c|c|c|c|c|c|c|}
\hline Treatment & FI (g/bird) & $\begin{array}{c}\text { Feed cost } \\
\text { (L.E/bird) }\end{array}$ & $\begin{array}{c}\text { *Total cost } \\
\text { (L.E/bird) }\end{array}$ & $\begin{array}{c}\text { BW } \\
\text { (g/bird) }\end{array}$ & $\begin{array}{c}* * \text { Total } \\
\text { Revenue } \\
\text { (L.E/bird) }\end{array}$ & $\begin{array}{c}\text { Net } \\
\text { Revenue } \\
\text { (L.E/bird) }\end{array}$ & E.E & $\begin{array}{l}\text { Relative } \\
\text { E.E (\%) }\end{array}$ \\
\hline Control & 3548.17 & 20.85 & 28.85 & 2225.67 & 66.77 & 37.92 & 1.31 & 100 \\
\hline $\operatorname{MOS}(0.5 \mathrm{~g} / \mathrm{kg})$ & 3415.33 & 20.22 & 28.22 & 2322.50 & 69.68 & 41.46 & 1.47 & 112 \\
\hline $\operatorname{MOS}(1 \mathrm{~g} / \mathrm{kg})$ & 3438.33 & 20.49 & 28.49 & 2282.00 & 68.46 & 39.97 & 1.40 & 107 \\
\hline $\operatorname{MOS}(2 \mathrm{~g} / \mathrm{kg})$ & 3391.83 & 20.50 & 28.50 & 2354.17 & 70.62 & 42.12 & 1.48 & 113 \\
\hline $\begin{array}{l}\text { Lincomycin } \\
(\mathrm{mg} / \mathrm{kg})\end{array}$ & 3434.33 & 20.19 & 28.19 & 2288.33 & 68.65 & 40.46 & 1.44 & 110 \\
\hline
\end{tabular}

*including chick price which was 8 L.E. **assuming the price of $1 \mathrm{~kg}$ live weight was $30 \mathrm{~L} . \mathrm{E} * * * a s s u m i n g$ the economic efficiency of the control was 100, BW: Body weight, E.E: Economic efficiency, MOS: Mannan oligosaccharides, FI: Feed intake.

\section{DISCUSSION}

\section{Productive performance}

In the current study, BW and BWG were the highest, and FCR was the best in the group fed $2 \mathrm{~g} \mathrm{MOS} / \mathrm{Kg}$ diet at trial days of the experiment as compared with the other experimental groups. This could be related to the mechanism of MOS, which results in a decrease in pathogenic bacteria load and an increase in beneficial bacteria production, leading to the establishment of a healthy intestinal environment. Consequently, absorption of nutrients in the intestine is enhanced and the performance is improved. In addition, MOS promotes the growth of caecal beneficial bacteria such as Bifidobacterium and Lactobacillus spp. in the intestine (Sadeghi et al., 2013). Therefore, the intestinal digestion and absorption of the nutrients were enhanced with the increased surface area of the villi (Chand et al., 2016) In addition, Mannan-oligosaccharide has been shown to enhance the growth parameters of the broiler chicks (Nikpiran et al., 2013).

Current results were in the same line with previous studies that found significant improvement of BW, BWG and FCR, when broiler chickens fed on a basal diet supplemented with $2 \mathrm{~g}$ MOS/Kg diet (Markovic et al., 2009; Ozduven et al., 2009; Esecel et al., 2012). Regarding the dose-response of MOS, the ideal dosage of MOS for optimal growth is approximately $2 \mathrm{~g} / \mathrm{kg}$ diet according to Tucker et al. (2003). Generally, Ozpinar et al. (2010) and Tufail et al. (2019) found that adding MOS to a broiler's diet increased chicks' BW and BWG compared to chicks that fed a basal diet without any supplementation.

Lincomycin is commonly used to prevent the infection caused by gram-positive pathogenic organisms in poultry. Antibiotic residues could be found in animal products such as eggs, meat, and milk, and they can cause a wide variety of symptoms in consumers, such as bacterial resistance or allergic reactions (Apata, 2009). Lincomycin, at low doses of 2.2 to $4.4 \mathrm{mg} / \mathrm{kg}$, has been demonstrated in numerous trials to improve weight gain and efficiency of food utilization (Stutz and Lawton, 1984; Dafwang et al., 1987). In contrast, Proudfoot et al. (2007) reported that there was not be more effective in both economically and biologically performance' improving by using lincomycin at $2.2 \mathrm{mg} / \mathrm{kg}$. As a result, antibiotics used as a growth promoter in animal feed can improve growth rates while still causing the development of resistance.

In the present study, broilers fed on a basal diet supplemented with lincomycin at a $4.4 \mathrm{mg} / \mathrm{kg}$ diet improved productive performance, compared to the control group, but was lower than the performance of MOS groups. In this regard, Jamal et al. (2017) reported that the FCR of the lincomycin group was better compared to the control group.

\section{Microbial content of caecum}

In the present study, the groups that fed on a basal diet supplemented with different levels of MOS showed an increase in Lactobacillus, Bifidobacterium and yeast count at the same time showed a decrease in E. coli and Enterococcus count. These findings might be attributed to MOS which increases the population of lactic acid bacteria in the intestinal tract of birds, resulting in the improved immune response against harmful bacteria such as $E$. coli and Enterococcus (Joerger, 2003; Patterson and Burkholder, 2003). Furthermore, the MOS supplements have specific receptors for E. coli fimbriae (sensitive to mannose) and Salmonella spp., resulting in the removal of these microorganisms with the digesta flow rather than binding to the intestinal receptor (Huyghebaert et al., 2011).

In this respect, (Castillo et al., 2008) stated that MOS can minimize the count of hindgut pathogenic bacteria during high exposure to the pathogen. This improvement in the intestinal microbial population is positively reflected in growth performance as indicated in the present study. The results of the current study were concurrent with those of Baurhoo et al. (2009a) indicating a decline in caecum E. coli count and an increase in Lactobacillus and Bifidobacteria spp. in broilers fed a diet supplemented with MOS, compared with broilers fed on a basal diet. A decline of caecum E. coli of broilers fed a basal diet supplemented with MOS, compared to broilers fed a basal diet without any supplements in the current study agrees with various studies (Baurhoo et al., 2009a; Baurhoo et al., 2009b; Koc et al., 2010). 
Concerning the comparison between lincomycin and MOS groups, the antibiotic additive is considered to be most effective against Gram-positive bacteria (Butaye et al., 2003), in comparison to the MOS treatments, the colonization of several common bacteria, such as lactobacilli, was inhibited. In agreement with current results, Jamroz et al. (2004) reported a greater decline of caecum $E$. coli for broilers fed a basal diet supplemented with $2 \mathrm{~g} \mathrm{MOS} / \mathrm{Kg}$ diet as compared with the group fed a basal diet supplemented with antibiotic (Avilamycin), Baurhoo et al. (2009a) reported that broilers fed a diet supplemented with $2 \mathrm{~g} \mathrm{MOS} / \mathrm{Kg}$ had a significant increase in Lactobacilli spp. and reduction of $E$. coli count in the caecum.

Results obtained herein showed that the $\mathrm{pH}$ levels were significantly decreased in the groups supplemented with MOS; this may be due to that MOS may increase ingesta fermentation which improves gut health in the distal intestine, resulting in the production of short-chain fatty acids (SCFA). The SCFAs play an important role in cell proliferation in the mucosa of the intestine. This lowers the $\mathrm{pH}$ of the brush boundary micro environment and prevents pathogen attachment (Lan et al., 2004; Oliveira et al., 2008). So, increased SCFAs in the intestinal digesta resulted in acidic gut ph. This mechanism may explain the better effects of MOS and microbial phytase concomitant use (Karimian and Rezaeipour, 2020).

\section{Blood parameters}

There was a gradually significant decrease in cholesterol and LDL as MOS levels increased in the diet while the group fed a basal diet supplemented with lincomycin showed a similar cholesterol level to the control group. Therefore, the group fed a basal diet supplemented with a $2 \mathrm{~g}$ MOS/kg diet showed the lowest cholesterol and LDL among all experimental groups. Concerning HDL, the groups fed a basal diet supplemented with $0.5 \mathrm{~g}$ or with $2 \mathrm{~g}$ MOS/ kg diet had significantly higher values. The most important mechanism upon which prebiotics reduce blood cholesterol levels is certainly through decreased intestinal lipid absorption by binding bile acids, leading to enhanced cholesterol excretion and hepatic synthesis of new bile acids (Ooi and Liong, 2010). Synthesis of bile acids from cholesterol in the liver is the most important way of cholesterol excretion (Wilson et al., 1998). In this connection, Biswas et al. (2019) reported that cholesterol level was decreased $(\mathrm{p}<0.05)$ in the $0.2 \%$ MOS group compared with other treated groups. Similarly, Kannan et al. (2005) and Juskiewicz et al. (2003) stated that serum total cholesterol concentration was significantly lower in broilers fed a $0.05 \%$ MOS diet when compared to a control diet. On the other hand, Muhammad et al. (2020) found a non-significant difference between levels of Mannan oligosaccharides $(0.5,1,1.5 \mathrm{~g} / \mathrm{kg} \mathrm{diet})$ among serum biochemical parameters and cholesterol levels.

Additionally, among all experimental groups, the group fed a basal diet supplemented with a $2 \mathrm{~g}$ MOS/ $\mathrm{kg}$ diet had the lowest ALT and AST levels. When compared to the control group, they were significantly lower in all treatment groups supplemented with MOS and Lincomycin. The current result was in agreement with Helal et al. (2015) who found a significant reduction in the AST and ALT in the chicks that received prebiotic in their diet as compared with chicks fed on antibiotics and basal diet. The result was in the same line with explanations of Jameel et al. (2014) who indicated a significant decrease in ALT and AST and declared that the differences might be due to the inclusion of different pre/probiotics, experimental plan executed, and management differences during rearing and environmental conditions. However, Muhammad et al. (2020) reported that the different levels of MOS (0.5, 1, $1.5 \mathrm{~g} / \mathrm{kg}$ diet) showed non-significant differences among serum biochemical parameters (ALT, AST) of treatment groups. Also, Biswas et al. (2019) reported that at 42 days, a significant increase $(\mathrm{p}<0.05)$ was recorded in AST at $0.2 \%$ MOS supplemented groups; whereas, no significant difference was observed in ALT concentration among the treated groups. The creatinine levels were significantly low for all experimental treated groups in comparison to those fed basal diet without supplementation. This was in line with the results of Helal et al. (2015) and Salim et al. (2011), who found a significant reduction in creatinine levels in the chicks that received prebiotics compared to the control group. However, Muhammad et al. (2020) reported no significant difference in creatinine levels among treatment groups.

The blood parameters showed that the group fed $2 \mathrm{~g} \mathrm{MOS} / \mathrm{Kg}$ diet had the significantly lowest blood urea among all experimental groups. The result agrees with Biswas et al. (2019) and disagrees with (Muhammad et al., 2020) who reported a non-significant difference among the urea levels between treatment groups.

The current result is in agreement with Iqbal et al. (2018) who reported that the different levels of MOS $(0.25,0.50$, and $1 \%$ ) for 15 weeks in Japanese quail breeders who found significant changes in HDL levels in treated groups compare the control group.

According to hematological results obtained in this study, a non-significant difference was recorded in RBCs, WBCs, and lymphocytes between all treatments group. The results are in agreement with Muhammad et al. (2020). Also, partly agree with the finding of Al-Saad et al. (2014) since no differences in RBCs were found between broilers fed a control diet supplemented with antibiotics (Lincomycin 100g/ton) and those fed diet supplemented with MOS (1000g/ton).

Whereas, the current result showed that the $\mathrm{Hb}$ was significantly the highest in the group fed dietary $2 \mathrm{~g} \mathrm{MOS} / \mathrm{Kg}$ diet compared with the control group. Moreover, $\mathrm{Hb}$ levels were significantly higher in all experimental treated groups 
as compared to the control group. The current result was not in the same line with studies of Muhammad et al. (2020) reported a non-significant difference among levels of $\operatorname{MOS}(0.5,1,1.5 \mathrm{~g} / \mathrm{kg}$ diet) regarding Hb of treatment groups. However, Abdel-Fattah and Fararh (2009) reported that there was a significant increase in Hb when they were used $1 \mathrm{~kg}$ of prebiotic (Bio-MOS ${ }^{\circledR}$ )/ton of feed compared with the basal diet fed, but a significant increase in RBCs count was detected in broilers fed prebiotic.

\section{Nutrient digestibility}

The current results showed a significant increase in CP digestibility in the diet supplemented with1 $\mathrm{g}$ MOS/Kg feed compared to other groups, and a significant decrease in group fed diet supplemented with lincomycin. However, the groups fed diets supplemented with 0.5 and $2 \mathrm{~g} \mathrm{MOS} / \mathrm{Kg}$ feed were similar in CP digestibility with the control group. The current study was in the same line with Afrouziyeh et al. (2014) who did not find a significant difference in CP digestibility between birds consuming treatments (0.1\% MOS, $0.2 \% \mathrm{MOS}$, and $0.3 \% \mathrm{MOS})$ and the control one. Also agree with Navidshad et al. (2015) in which the digestibility coefficients of CP were similar for the control and $2 \mathrm{~g} / \mathrm{kg}$ Bio-Mos ${ }^{\circledR}$ supplemented diets.

Overall, groups fed a diet supplemented with MOS at $2 \mathrm{~g} / \mathrm{kg}$ feed had the best OM digestibility among all experimental groups, this is probably due to the increase in the digestion and absorption of nutrients and reduced the number of pathogenic bacteria (E. coli, Enterococcus) as well as increased the beneficial bacteria (Lactobacilli) in the intestine that is important to improve growth performance. This is in agreement with Afrouziyeh et al. (2014) who recorded that the organic matter $(\mathrm{OM})$ was significantly higher in broilers fed a diet supplemented with $0.2 \mathrm{~g} \mathrm{MOS} / \mathrm{Kg}$ diet compared to the other treatment groups. Similarly, Huang et al. (2005) showed that oligosaccharide supplementation enhanced nutrient digestibility and feed efficiency in broiler chicks. The improvement of nutrient digestibility in broilers fed diets supplemented with oligosaccharides might be attributed to gut health improvement (Tuohy et al., 2003).

\section{Intestinal histopathology}

In this study, the length of intestinal villi, villus width, and crypt depth in all treated groups of broiler chickens were significantly increased compared to the control group. The improvement observed in the intestinal villi length can be attributed to the increase in Lactobacillus count in the treated groups. Accordingly, increased levels of beneficial bacteria such as lactobacillus can lead to promoting the development of a healthy intestinal environment, resulting in an increase in villi length due to competitive exclusion (Baurhoo et al., 2009b).

Dietary inclusion of antibiotics also reduces the weight and length of the intestines in poultry (Postma et al., 1999). Results obtained in the present study were in accordance with those of Baurhoo et al. (2009a) who reported that on day 34 of age, dietary MOS of $2 \mathrm{~g}$ and $5 \mathrm{~g}$ MOS/kg significantly increased villus height in all intestinal segments, compared to virginiamycin $(0.002 \%)$ and bacitracin $(0.006 \%)$. Similarly, Sinovec et al. (2005) reported that MOS (0.2\%) significantly improved broiler villus height in all areas of the small intestine when compared to birds supplemented with (Flavomycin $0.002 \%$ ) and control diets. Furthermore, the study of Karimian and Rezaeipour (2020) reported that the dietary MOS $2 \mathrm{~g} / \mathrm{kg}$ diet significantly increased villus height compared to the basal diet. Although, previous studies indicated no variation in villus height between broilers fed MOS and those fed other dietary treatments (Oliveira et al., 2008; Baurhoo et al., 2009b).

A greater surface area for nutrient absorption due to long villi and shallow crypts, and a low renewal rate allow efficient enzyme synthesis and intestinal cell maturation (Yang et al., 2009). Previous studies however reported that the depths of crypts were increased in broiler chicks fed MOS (0.1 and $0.5 \%$ of diet), compared to the control group which is similar to the current study (Iji et al., 2001; Oliveira et al., 2008). Present results however are not in the same line with those of Yang et al. (2009) who indicated that MOS reduced crypt depth in the broiler's small intestine. Similarly, Sinovec et al. (2005) showed that the crypt depth was reduced in all parts of the small intestine of broilers in response to $0.2 \%$ MOS in the diet, compared to both Flavomycin at $0.002 \%$ and control diets.

Increased stress and pathogen load can alter immune responses facilitating infection, host tissue damage, and inflammation (Berghman, 2016). Inflammation, therefore, is considered the most predominant reaction of innate defense to alterations in tissue homeostasis (Medzhitov, 2008). In the current study, the intestine of chicken in the control group and group supplemented with lincomycin showed mild to moderate inflammation of the intestine whereas the groups supplemented with MOS especially the group supplemented with the high dose of MOS showed a decrease in intestinal inflammation and few leukocytes infiltration. Likewise, a previous study showed that MOS and live yeast supplementation was able to control intestinal inflammation by attenuating $E$. coli-induced intestinal disruption in broilers (Tarradas et al., 2020).

\section{Economic efficiency}

The current investigation indicated that the group fed diet supplemented with lincomycin had the least feed cost among all groups and the group fed diet supplemented with $0.5 \mathrm{~g} \mathrm{MOS} / \mathrm{Kg}$ diet recorded lower feed cost compared to 
other MOS doses. Besides, both Lincomycin and MOS treatment groups exhibited higher values of net revenue and EE compared to the control. However, chicks which were fed diets supplemented with MOS at $2 \mathrm{~g} / \mathrm{kg}$ were the best. Hooge et al. (2003) confirmed our results on broiler chicks that fed during their first 49 days of age, with 0 (negative control), 0.5, and $1 \mathrm{~g}$ Bio-Mos/kg in different periodical diets. Also, Nazir et al. (2017) reported that the broiler chicks fed on a diet supplemented with lincomycin $(6.5 \mathrm{mg} / \mathrm{kg}$ diet $)$ were more economical, compared to the control group. However, Eseceli et al. (2010) did not show any significant differences in feed cost kg-1 BWG between three broiler chick groups fed on diets supplemented with 0.5 , 1 , or $1.5 \mathrm{~g}$ Bio-Mos/ $\mathrm{kg}$ diet.

There are a very limited number of researchers interested in the economic aspect of Bio-Mos inclusion in poultry diets. Therefore, a higher dose rate of MOS may be evaluated for better results provided that economic parameters are not compromised. These improvements could be attributed to the improved body weight gain, feed conversion, and low prices of Mannan oligosaccharides and lincomycin, compared to the control group.

\section{CONCLUSION}

In the current study, three Mannan oligosaccharides concentrations were used $(0.5,1$, and $2 \mathrm{~g} / \mathrm{kg})$, in addition to Lincomycin (4.4) $\mathrm{mg} / \mathrm{kg}$ as feed additives. Mannan concentration of $2 \mathrm{~g} / \mathrm{kg}$ supplementation had the best results for growth performance, histopathological examination, and biochemical properties. Further investigations are needed to optimize the recommended concentrations.

\section{DECLARATIONS}

\section{Authors' contribution}

All authors contributed equally in conceiving the idea and writing the first draft and the revised version.

\section{Competing interests}

The authors declare no conflicts of interest in the present study.

\section{Ethical consideration}

Ethical issues (including plagiarism, consent to publish, misconduct, double publication and/ or submission, and redundancy) have been checked by the authors.

\section{Consent to publish}

Hereby, the authors agreed to publish the article.

\section{Acknowledgments}

The present study was funded by the Faculty of Agriculture, Cairo University, Egypt, and the authors would like to express their appreciation.

\section{REFERENCES}

Abdel-Fattah FA, and Fararh KM (2009). Effect of dietary supplementation of probiotic, prebiotic and synbiotic on performance, carcass characteristics, blood picture and some biochemical parameters in broiler chickens. Benha Veterinary Medical Journal, 20: 9-23. Available at: https://fvtm.stafpu.bu.edu.eg/Nutritient $\% 20$ and $\% 20$ clinical $\% 20$ Nutrition/1063/publications/Fathy $\% 20$ Attia $\% 20$ Ismaiel $\% 20$ Abde lfattah_2-2009-\%20Probiotic.pdf

Abou-Raya AK, and Galal AGH (1971). Evaluation of poultry feeds in digestion trials with reference to some factors involved. Egyptian Journal Animal Production, 11: 207-221. DOI: http://www.dx.doi.org/10.21608/ejap.1971.151463

Afrouziyeh M, Hanifian SH, and Taghinejad M (2014). Effects of mannan oligosaccharides on ileal digestibility of nutrients and microbial populations in the ceca of broiler chickens. International. International Journal of Biosciences, 5(1): 373-380. DOI: http://www.dx.doi.org/10.12692/ijb/5.1.373-380

Al-Saad S, Abbod M, and Abo Yones A (2014). Effects of some growth promoters on blood hematology and serum composition of broiler chickens. International journal of agricultural research, 9: 265-270. DOI: http://www.dx.doi.org/10.3923/ijar.2014.265.270

Association of Official Analytical Chemists (AOAC) (2016). Association of official analytical chemists of official methods of analysis (20th edition). Washington, DC, USA. Available at: https://www.techstreet.com/standards/official-methods-of-analysis-of-aoacinternational-20th-edition-2016?product_id=1937367

Apata DF (2009). Antibiotic resistance in poultry. International Journal of Poultry Science, 4: 404-408. DOI: http://www.dx.doi.org/10.3923/ijps.2009.404.408

Attia YA, Al-Hamid AA, Ibrahim MS, Al-Harthi MA, Bovera F, and Elnaggar AS (2014). Productive performance, biochemical and hematological traits of broiler chickens supplemented with propolis, bee pollen, and Mannan oligosaccharides continuously or intermittently. Livestock Science, 164: 87-95. DOI: http://www.dx.doi.org/10.1016/j.livsci.2014.03.005

Bahman AH, Alireza T, and Siamak AR (2011). Comparative study on blood profiles of indigenous and Ross-308 broiler breeders. Global Veterinaria 7(3): 238-241. Available at: https://www.idosi.org/gv/GV7(3)11/6.pdf 
Baurhoo B, Ferket PR, and Zhao X (2009a). Effects of diets containing different concentrations of Mannan oligosaccharide or antibiotics on growth performance, intestinal development, caecal and litter microbial populations, and carcass parameters of broilers. Poultry Science, 88: 2262-2272. DOI: http://www.dx.doi.org/10.3382/ps.2008-00562

Baurhoo B, Goldflus F, and Zhao X (2009b). Purified cell wall of Saccharomyces cerevisiae increases protection against intestinal pathogens in broiler chickens. International Journal of Poultry Sciences, 8: 133-137. DOI: http://www.dx.doi.org/10.3923/ijps.2009.133.137

Berghman LR (2016). Immune responses to improving welfare. Poultry Science, 95: 2216-2218. DOI: http://www.dx.doi.org/10.3382/ps/pew159

Biswas A, Namit M, Messam R, Nasir AM, and Asitbaran M (2019). Production performance, immune response and blood biochemical parameters in broiler chickens fed diet incorporated with prebiotics. Journal of Animal Physiology and Animal Nutrition, 103(2): 493-500. DOI: http://www.dx.doi.org/10.1111/jpn.13042

Butaye P, Devriese LA, and Haesebrouck F (2003). Antimicrobial growth promoters used in animal feed: Effects of less well known antibiotics on gram-positive bacteria. Clinical Microbiology Reviews, American Society for Microbiology, 16(2): 175-188. DOI: http://www.dx.doi.org/10.1128/cmr.16.2.175-188.2003

Castillo M, Martin-Orue SM, Taylor-Pickard JA, JF Perez JF, and Gasa J (2008). Use of Mannan oligosaccharides and zinc chelate as growth promoters and diarrhea preventative in weaning pigs: Effects on microbiota and gut function. Journal of Animal Science, 86: 94-101. DOI: http://www.dx.doi.org/10.2527/jas.2005-686

Chand N, Faheem H, Khan RU, Qureshi MS, Alhidary IA, and Abudabos AM (2016). Anticoccidial effect of Mannan oligosaccharide against experimentally induced coccidiosis in broiler. Environmental Science and Pollution Research, 23: 14414-14421. DOI: http://dx.doi.org/10.1007/s11356-016-6600-x

Collin CH, Lyne PM and Grange JM (1995). Collin and Lyn's microbiological methods. Journal of Medical Microbiology, 43 : 512. DOI: http://www.dx.doi.org/10.1099/00222615-43-4-310b

Dafwang II, Cook ME, and Sunde ML (1987). Interaction of dietary antibiotic supplementation and stocking density on broiler chick performance and immune response. British Poultry Science, 28(1): 47-55. DOI: http://www.dx.doi.org/10.1080/00071668708416935

Duncan DB (1955). The multiple ranges and multiple F-Tests. Biometrics, 11: 1-42. DOI: http://dx.doi.org/10.2307/3001478

Eseceli H, Demir E, Degirmencioglu N, and Bilgic M (2010). The effects of Bio-Mos ${ }^{\circledR}$ Mannan oligosaccharide and antibiotic growth promoter performance of broilers. Journal of Animal and Veterinary Advances, 9: 392-395. DOI: http://www.dx.doi.org/10.3923/javaa.2010.392.395

Ewuola EO, and Egbunike GN (2008). Haematological and serum biochemical response of growing rabbits bucks fed different levels of dietary fumonisin. African Journal of Biotechnology, 7: 4304-4309. Available at: https://www.ajol.info/index.php/ajb/article/view/59575

Helal M, Youssef F, Moursi M, Khalil W, and Abdel-Daim M (2015). The effectiveness of prebiotic as an alternative to the antimicrobial growth promoter on growth performance, blood constituents, intestinal healthiness and immunity of broilers. Alexandria Journal of Veterinary Sciences, 45: 13-25. DOI: https://www.doi.org/10.5455/ajvs.179869

Higgins SE, Higgins JP, Wolfenden AD, Henderson SN, Torres-Rodriguez A, Tellez G, and B Hargis (2008). Evaluation of a Lactobacillus-based probiotic culture for the reduction of Salmonella enteritidis in neonatal broiler chicks. Poultry Science, 87: 27-31. DOI: https://www.doi.org/10.3382/ps.2007-00210

Hooge DM, Sims MD, Sefton AE, Connolly A, and Spring P (2003). Effect of dietary mannan oligosaccharide, with or without bacitracin or virginiamycin, on live performance of broiler chickens at relatively high stocking density on new litter. Journal of Applied Poultry Research, 12: 461-467. DOI: https://www.doi.org/10.1093/japr/12.4.461

Huang GL, Liu MX, and Mei XY (2005). Studies on the hydrolytic condition of $\beta-1,3$ glucan from yeast by fluorophore-assisted carbohydrate electrophoresis. Analytical Letters, 38: 477-485. DOI: https://www.doi.org/10.1081/al-200047797

Huyghebaert G, Ducatelle R, and van Immerseel F (2011). An update on alternatives to antimicrobial growth promoters for broilers. The Veterinary Journal, 187: 182-188. DOI: https://www.doi.org/10.1016/j.tvj1.2010.03.003

Iji PA, Saki AA, and Tivey DR (2001). Intestinal development and body growth of broiler chicks on diets supplemented with nonstarch polysaccharides. Animal Feed Science and Technology, 89: 175-188. DOI: https://www.doi.org/10.1016/s0377$\underline{8401(00) 00223-6}$

Iqbal MA, Roohi N, and Khan O (2018). Dietary supplemented effects of Mannan oligosaccharides on biochemical parameters of 4 close-bred flocks of Japanese quail breeders. Poultry Science, 97: 3718-3727. DOI: https://www.doi.org/10.3382/ps/pey210

Jakobsen PE, Gertov K, and Nilsen SH (1960). Frdjelighed frogmed fierbrae. "Digestibility trails with poultry". Bereting fra for sogslabortoriet, Kabenhaven, 56: 1-34.

Jamal M, Munazza S, and Sanaullah S (2017). Lincomycin and tetracycline resistance in poultry. Review. Matrix Science Pharma (MSP) 1(1): 33-38. DOI: https://www.doi.org/10.26480/msp.01.2017.33.38

Jameel YJ, Abed A, and Al-Shimmary F (2014). Influence of adding garlic and thyme and their combination on immune response and some blood parameters in broiler. International Journal of Advanced Biological Research, 2: 102-106. Available at: http://www.scienceandnature.org/IJABR/IJABR Vol4(2)2014/IJABR V4(2)14-20.pdf

Jamroz D, Wiliczkiewicz A, Orda J, Wertelecki T, and Skorupinska J (2004). Response of broiler chickens to the diets supplemented with feeding antibiotic or mannan-oligosaccharides. Electronic Journal of Polish Agricultural Universities, 7: 1-6. Available at: https://www.infona.pl/resource/bwmeta1.element.agro-article-a62a1229-ae6a-413a-9a00-ab6710b54655

Joerger RD (2003). Alternatives to antibiotics: bacteriocins, antimicrobial peptides and bacteriophages. Poultry Science, 82: 640-647. DOI: https://www.doi.org/10.1093/ps/82.4.640

Juskiewicz J, Zdunczyk Z, and Jankowski J (2003). Effect of adding mannan-oligosaccharide to the diet on the performance, weight of digestive tract segments, and caecal digesta parameters in young turkeys. Journal of Animal and Feed Sciences, 12: 133-142. DOI: https://www.doi.org/10.22358/jafs/67690/2003 
Kannan M, Karunakaran R, Balakrishnan V, and Prabhakar TG (2005). Influence of prebiotics supplementation on lipid profile of broilers. International Journal of Poultry Science, 4: 994-997. DOI: https://www.doi.org/10.3923/ijps.2005.994.997

Karimian RA, and Rezaeipour V (2020). Effects of dietary Mannan oligosaccharides and phytase supplementation alone or in combination on growth performance, serum metabolites, cecal microbiota activity and intestinal morphology in broiler chickens. Poultry Science Journal, 8(1): 27-32. DOI: https://www.doi.org/10.22069/psj.2020.17229.1513

Kim CH, Shin KS, Woo KC and Paik IK (2009). Effect of dietary oligosaccharides on the performance, intestinal microflora and serum immunoglobulin contents in laying hens. Korean Journal of Poultry Science, 36: 125-131. DOI https://www.doi.org/10.5536/kjps.2009.36.2.125

Kim SJ, Lee KW, Kang CW, and An BK (2016). Growth performance, relative meat and organ weights, cecal microflora, and blood characteristics in broiler chickens fed diets containing different nutrient density with or without essential oils. Asian-Australasian Journal of Animal Sciences, 29(4): 549. DOI: https://www.doi.org/10.5713/ajas.15.0426

Koc F, Samli H, Okur A, Ozduven M, and Senkoylu HAN (2010). Effects of saccharomyces cerevisiae and/or Mannan oligosaccharide on performance, blood parameters and intestinal microbiota of broiler chicks. Bulgarian Journal of Agricultural Science, 16: 643-650. https://www.agrojournal.org/16/05-15-10.pdf

Kovitvadhi A, Chundang P, Tirawattanawanich C, Prathumpai W, Methacanon P, and Chokpipatpol K (2019). Effects of dietary supplementation with different levels and molecular weights of fungal $\beta$-glucan on performances, health and meat quality in broilers. Asian-Australas Journal Animal Science, 32: 1548-1557. DOI: https://www.doi.org/10.5713/ajas.18.0927

Lan PT, Sakamoto M, and Benno Y (2004). Effects of two probiotic Lactobacillus strains on jejunal and cecal microbiota of broiler chicken under acute heat stress condition as revealed by molecular analysis of 16S rRNA genes. Microbiology and Immunology, 48: 917-929. DOI: https://doi.org/10.1111/j.1348-0421.2004.tb03620.x

Leblebicier ODY and Aydoğan I (2018). The Effects of Mannan Oligosaccharide and Chitosan Oligosaccharide on Performance and Blood Parameters of Broilers. Journal of Poultry Research, 15(1): 18-22. Available at: https://dergipark.org.tr/tr/download/articlefile $/ 512235$

Mahfuz S, Song H, Miao Y, and Liu Z (2019). Dietary inclusion of mushroom (Flammulina velutipes) stem waste on growth performance and immune responses in growing layer hens. Journal of the Science of Food and Agriculture, 99(2): 703-10. DOI: https://www.doi.org/10.1002/jsfa.9236

Markovic R, Sefer D, Krsti M, and Petrujki B (2009). Effect of different growth promoters on broiler performance and gut morphology. Archivos de Medicina Veterinaria, 41(2): 163-169. DOI: https://www.doi.org/10.4067/s0301-732x2009000200010

Medzhitov R (2008). Origin and physiological roles of inammation. Nature, 454: $428-435.4$ DOI: https://www.doi.org/10.1038/nature07201

Mohamed FF, Hady MM, Kamel NF, and Ragaa NM (2020). The impact of exogenous dietary nucleotides in ameliorating Clostridium perfringens infection and improving intestinal barriers gene expression in broiler chicken. Veterinary and Animal Science, 10: 19. DOI: https://www.doi.org/10.1016/j.vas.2020.100130

Muhammad SL, Sheikh IS, Bajwa MA, Mehmood K, Rashid N, Akhter MA, ullah Jan S, Rafeeq M, Babar W, Magsi RA et al. (2020). Effect of Mannan oligosaccharides (MOS) on growth, physiological and immune performance of broiler chickens. Pak-Euro Journal of Medical and Life Sciences, 3(2): 76-85. DOI: https://www.doi.org/10.31580/pjmls.v3i2.1379

National Research Council (NRC) (1994). Nutrient requirements for poultry. 9th revised edition, National Academy Press, Washington DC. Available at: https://www.nap.edu/catalog/2114/nutrient-requirements-of-poultry-ninth-revised-edition-1994

Navidshad B, Juan Boo Liang, Mohammad FJ, Amir A, and Norhani A (2015). A comparison between a yeast cell wall extract (Bio$\operatorname{Mos}^{B}$ ) and palm kernel expeller as mannan-oligosaccharides sources on the performance and ileal microbial population of broiler chickens. Italian Journal of Animal Science, 14: 3452. DOI: https:/www.doi.org/10.4081/ijas.2015.3452

Nazir A, Aziz UM, Shahzad Ak, Zulfiqar HK, Faisal R, Zulfiqar A, Imran AAS, and Atif A (2017). Study on the effects of antibiotic (Lincomycin) and feed additive (Niacin) on the Growth of Broilers. Global Veterinarian, 18(5): 335-342. DOI: https://www.doi.org/10.5829/idosi.gv.2017.335.342

Nikpiran H, Vahdatpour T, Babazadeh D, and Vahdatpour S (2013). Effects of saccharomyces cerevisiae the pax and their combination on blood enzymes and performance of Japanese quails (Coturnix japonica). The Journal of Animal and Plant Sciences, 23: 369375. Available at: http://www.thejaps.org.pk/docs/v-23-2/06.pdf

Oliveira MC, Rodrigues EA, Marques RH, Gravena RA, Guandolini GC, and Moraes VMB (2008). Performance and morphology of intestinal mucosa of broilers fed mannan-oligosaccharides and enzymes. Arquivo Brasileiro de Medicina Veterinária e Zootecnia, 60(2): 442-448. DOI: https://www.doi.org/10.1590/s0102-09352008000200025

Ooi LG, and Liong MT (2010). Cholesterol-lowering effects of probiotics and prebiotics: a review of in vivo and in vitro findings. International Journal of Molecular Sciences, 11: 2499-2522. DOI: https://www.doi.org/10.3390/ijms 11062499

Ozduven ML, Samli HE, Okur AA, Koc F, Akyurek H, and Senkoylu N (2009). Effects of Mannan oligosaccharide and/or organic acid mixture on performance, blood parameters and intestinal microbiota of broiler chicks. Italian Journal of Animal Science, 8 : 595-602. DOI: https://www.doi.org/10.4081/ijas.2009.595

Ozpinar H, Erhard M, Ahrens F, Kutay C, and Eseceli H (2010). Effects of Vitamin E, Vitamin C and Mannan oligosaccharides (BioMOS) supplementation on performance and immune system in broiler chicks. Journal of Veterinary and Animal Advances, 9: 2647-2654. DOI: https://www.doi.org/10.3923/javaa.2010.2647.2654

Patterson JA, and Burkholder KM (2003). Application of prebiotics and probiotics in poultry production. Poultry Science, 82: 627631. DOI: https://www.doi.org/10.1093/ps/82.4.627

Postma J, Ferket PR, Croom WJ, and Kwakkel RP (1999). In: Proceedings of the $12^{\text {th }}$ European symposium on poultry nutrition. (R.P. Kwakkel and J.P.M. Bos, editors). World's Poultry Science Association, Dutch branch. Het Spelderholt, Beekbergen, the Netherlands, p. 188. Available at: https://research.wur.nl/en/publications/proceedings-of-the-12th-european-symposium-onpoultry-nutrition-w

Pourabedin M, and Zhao X (2015). Prebiotics and gut microbiota in chickens. FEMS Microbiology Letters, 362(15): fnv122. DOI: https://www.doi.org/10.1093/femsle/fnv122 
Proudfoot FG, Hulan HW, Jackson ED, and Salisbury CDC (1990). Effect of Lincomycin as a growth promoter for broiler chicks. British Poultry Science, 31(1): 181-187. DOI: https://www.doi.org/10.1080/00071669008417244

Rafeeq MM, and Murad H AS (2017). Cystic fibrosis: current therapeutic targets and future approaches. Journal of Translational Medicine, 15: 84. DOI: https://www.doi.org/10.1186/s12967-017-1193-9

Ross AH, Van der kamp HJ, and Marley EC (1997). Comparison of immune affinity columns with Florisil/C18 columns for the determination of aflatoxins in animal feed and maize. Mycotoxin Research, 13: 2-10. DOI: https://www.doi.org/10.1007/bf02945056

Saad TT, Atallah ST, and El-Bana SA (2014). Fish diseases and its economic effect on Egyptian fish farms. Journal of Agriculture and Food Technology, 4(5): 1-6. Available at: https://www.textroad.com/pdf/JAFT/J.\%20Agric.\%20Food.\%20Tech.,\%204(5)1$\underline{6, \% 202014 . p d f}$

Sadeghi AA, Mohammadi A, Shawrang P, and Aminafshar M (2013). Immune responses to dietary inclusion of prebiotic-based mannan-oligosaccharide and $\beta$-glucan in broiler chicks challenged with Salmonella enteritidis. Turkish Journal of Veterinary and Animal Sciences, 37: 206-213. DOI: https://www.doi.org/10.3906/vet-1203-9

Salim HA, Abd-Allah OA, and Fararh KM (2011). Clinico pathological study on the effect of beta-glucan on hematological and immunological and biochemical changes in broiler chicks. Benha Veterinary Medical Journal, 22(2): 70-79. Available at: https://www.bu.edu.eg/portal/uploads/openLearning/CLINICOPATHOLOGICAL\%20STUDY\%200N\%20THE\%20EFFECT\%2 0OF\%20BETA-

GLUCAN\%20ON\%20HEMATOLOGICAL\%20AND\%20IMMUNOLOGICAL\%20AND\%20BIOCHEMICAL\%20CHANGES \%20IN\%20BROILER\%20CHICKS paper en.pdf

Statistical Analysis System (SAS) (2010). SAS/STAT User's Guide, Version 9.1.SAS Institute Inc., Cary, NC.USA.

Sinovec Z, Markovic R and Gledic D (2005). Influence of Bio-Mos on broiler performances and gut morphology. Proceedings of the 15th European Symposium on Poultry Nutrition, 339-341. https://www.cabi.org/Uploads/animal-science/worlds-poultry-scienceassociation/WPSA-hungary-2005/352-355Sinovec.pdf

Spring P (1996). Effects of Mannan oligosaccharide on different caecal parameters and on caecal concentrations of enteric pathogens in poultry. Ph.D. Dissertation, Swiss Federal Institute of Technology, Zurich, Switzerland. Available at: https://www.researchcollection.ethz.ch/bitstream/handle/20.500.11850/142858/eth-40507-02.pdf

Sturkie PD (1954). Avian Physiology, Chapter 13, Comstock Publishing; Ithaca, New York.

Stutz MW, and Lawton GC (1984). Effects of diet and antimicrobials on growth, feed efficiency, intestinal Clostridium perfringens, and ileal weight of broiler chicks. Poultry science, 63: 2036-2042. DOI: https://www.doi.org/10.3382/ps.0632036

Suvarna SK, Layton C, and Bancroft JD (2012). Bancroft's theory and practice of histological techniques. 7th edition, New York: Churchill Livingstone. Available at: https:/www.sciencedirect.com/book/9780702042263/bancrofts-theory-and-practice-ofhistological-techniques

Sweeney MT, Lubbers BV, Schwarz S, and Watts JL (2018). Applying definitions for multidrug resistance, extensive drug resistance and pandrug resistance to clinically significant livestock and companion animal bacterial pathogens. Journal of Antimicrobial Chemotherapy, 73: 1460-1463. DOI: https://www.doi.org/10.1093/jac/dky043

Tarradas J, Tous N, Esteve-Garcia E, and Brufau AJ (2020). The control of intestinal inflammation: A major objective in the research of probiotic strains as alternatives to antibiotic growth promoters in poultry. Microorganisms, 8(2): 148. DOI: https://www.doi.org/10.3390/microorganisms8020148

Tucker L, Esteve-Garcia E, and Connolly A (2003). Dose response of commercial Mannan oligosaccharides in broiler chickens, WPSA $14^{\text {th }}$ European Symposium on Poultry Nutrition. Lillehammer, Norway. Available at: https://www.cabi.org/animalscience/worlds-poultry-science-association-wpsa/wpsa-hungary-2005/

Tufail M, Naila C, Rafiullah, Shakoor A, Rifat UK, Muhammad M, and Shabana N (2019). Mannan oligosaccharide (mos) in broiler diet during the finisher phase: 2. growth traits and intestinal histomorpholgy. Pakistan Journal of Zoology, 51(2): 597-602. DOI: https://doi.org/10.17582/journal.pjz/2019.51.2.597.602

Tuohy KM, Probert HM, Smejkal CW and Gibson GR (2003). Using probiotics and prebiotics to improve gut health. Drug discovery today, 8 (15): 692-700. DOI: https://doi.org/10.1016/s1359-6446(03)02746-6

Wilson PW, Agostino RBD, Levy D, Belanger AM, Silbershatz H, and Kannel WB (1998). Prediction of coronary heart disease using risk factor categories. Circulation, 97: 1837-1847. DOI: https://www.doi.org/10.1161/01.cir.97.18.1837

Yang Y, Iji PA, and Choct M (2009). Dietary modulation of gut microflora in broiler chickens: a review of the role of six kinds of alternatives to in-feed antibiotics. World's Poultry Science Journal, 65(1): 97-114. DOI: https://doi.org/10.1017/S0043933909000087 